\title{
SLC16A11 wt Allele
}

National Cancer Institute

\section{Source}

National Cancer Institute. SLC16A11 wt Allele. NCI Thesaurus. Code C115024.

Human SLC16A11 wild-type allele is located in the vicinity of 17p13.1 and is approximately $2 \mathrm{~kb}$ in length. This allele, which encodes monocarboxylate transporter 11 protein, plays a role in monocarboxylate transport. Variation of the gene is associated with susceptiblility to non-insulin dependent diabetes mellitus. 